\title{
NON PUNITIVE ACTION TERHADAP PILOT AKIBAT KECELAKAAN DAN INSIDEN SERIUS PESAWAT UDARA SIPIL DI INDONESIA
}

\author{
Rivay Frien Danu \\ Email: rfriendanu@outlook.com \\ Mahasiswa Magister Ilmu Hukum Fakultas Hukum UNS Surakarta \\ Widodo Tresno Novianto, Hartiwiningsih \\ Email: novianto@consultant.com, hartiwi@yahoo.com, \\ Dosen Fakultas Hukum UNS Surakarta
}

\begin{abstract}
The sole objective of this article for finding out the urgention of the non punitive action implementation for the civil aviation accident and serious incident and the steps to accomply $i t$. This research is normative study research with statute approach and comparative approach study in national and international level. The legal matterial of this research are primary legal matterial and secondary legal material with deductive analystic mind. Reffering the research above, showed that Indonesia as contracting state of Chicago Convention 1944 through joining with International Civil Aviation Organization, Indonesia need implemented the non punitive action in accident and serious incident of civil aviation through mandatation in Annex 13 ICAO. The mandate of that annex base on just culture principle and it said that everyone especially the aviation personel do not given punishment from the regulator reffered by the violation valued, so base on that act, the personel must be punished, because the just culture principle not recognize the punishment of the safety act that reffered on their experience and training. If the punitive culture still on hand, it can implicated to the contraproductive of corrective action from the accident and serious incident happening and unjust feeling of the personel affected by the punishment by the consequent of accident and serious incident. For realize the non punitive action culture for created safety culture, need the following action as recomendation in this research, such as determination of unsafe act, evaluation of national law which inconsistent with just culture principle, and the estabilished the pilot proffesion council
\end{abstract}

Keywords: Non Punitive Action; Just Culture; Civil Aviation Accident and Serious Incident

\begin{abstract}
Abstrak
Tujuan penelitian ini adalah mengetahui urgensi penerapan non punitive action terhadap kecelakaan dan insiden serius pesawat udara sipil dan langkah upaya untuk mewujudkannya. Penelitian ini merupakan studi normatif dengan pendekatan perundang-undangan dan perbandingan. Bahan hukum yang digunakan berupa bahan hukum primer berupa peraturan perundang-undangan ditingkat nasional maupun internasional dan bahan hukum sekunder yang digunakan berupa pendapat ahli, jurnal, dan literatur non hukum dengan pola analisis deduktif. Dari hasil penelitian, menunjukan bahwa Indonesia sebagaicontracting state terhadap Konvensi Chicago 1944 melalui bergabungnya Indonesia pada International Civil Aviation Organization, Indonesia perlu menerapkan prinsip non punitive action terhadap pilot akibat kecelakaan dan insiden serius pesawat udara sipil, yang diamanatkan melalui Annex 13 ICAO. Amanat tersebut didasarkan pada prinsip just culture yang berprinsip bahwa setiap manusia khususnya personel penerbangan tidak dapat diberi penghukuman terhadap tindakan yang dinilai salah sehingga
\end{abstract}


atas perbuatan tersebut personel tersebut harus dihukum, karena dalam prinsip just cultureyang merupakan bagian dari safety culture, tidak mengenal penghukuman atas sebuah tindakan maupun keputusan yang merupakan yang diperoleh dari pengalaman dan pelatihan personel tersebut, akan tetapi just culture juga tidak memberikan toleransi akibat kesalahan yang bersifat intentional violation. Apabila budaya punitive action tetap terpelihara, maka berimplikasi pada terhambatnya upaya corrective action dari peristiwa kecelakaan maupun insiden serius serta rasa ketidak adilan terhadap personel yang diberi sanksi akibat kecelakaan maupun insiden serius. Untuk mewujudkan budaya non punitiveaction agar terciptanya safety culture tersebut, diperlukan upaya-upaya yang mengikutinya sebagai rekomendasi dalam penelitian ini, antara lain pendeterminasian terhadap unsafe act, evaluasi hukum nasional yang inkonsisten dengan just culture, serta pembentukan majelis profesi penerbang.

Kata Kunci: Non Punitive Action; Just Culture; Kecelakaan dan insiden serius pesawat udara sipil

\section{A. Pendahuluan}

Hukum merupakan suatu instrumen yang dibuat sebagai sekumpulan norma baik tertulis maupun tidak tertulis terkait benar atau salahnya tindakan dan perilaku seseorang, sehingga definisi tersebut berkembang menjadikan hukum sebagai ketentuanketentuan yang di gariskan oleh pemerintah untuk mengatur hak dan kewajiban yang legal (William J. Chamblis, 1971:18). Hal tersebut membuat pandangan mengenai hukum menjadi mengabaikan fakta ketika struktur dan peraturannya tidak dapat menjelaskan bagaimana mesinnya bekerja, sehingga hal ini berimplikasi pada tidak terlihatnya mengenai bagaimana dan mengapa peraturan di buat dan efek yang dihasilkan (Lawrence M. Friedman, 2011:2).

Peraturan-peraturan yang di berlakukan terhadap seseorang ataupun sebuah sistem merupakan tindakan hukum (legal acts) yang memiliki dampak. Tindakan hukum tersebut akan dikatakan efektif ketika subjek hukum patuh terhadap peraturan yang di buat (Lawrence M. Friedman, 2011:2). Apabila dampak dari suatu peraturan maupun kebijakan berdampak positif tentunya tidak akan menjadi masalah, namun akan menjadi masalah bilamana tindakan hukum yang dilakukan berdampak negatif sehingga mempengaruhi esensi, maksud, dan tujuan dari suatu peraturan perundang-undangan. Hal tersebut dapat ditemukan sebagai contoh pada Pasal 479 Kitab Undang-Undang Hukum Pidana (Selanjutnya disebut KUHP), berisi mengenai kejahatan terhadap sarana/ prasarana penerbangan. Pasal ini dipakai oleh penegak hukum dalam menuntut penerbang (selanjutnya disebut pilot) sebagai pihak yang bertanggung jawab oleh karena kelalaiannya menyebabkan kecelakaan pesawat udara, sehingga pesawat udara tersebut rusak atau hancur. Hal tersebut pernah terjadi pada kasus kecelakaan pesawat udara Garuda Indonesia dengan nomor penerbangan GA 200 dengan rute dari Bandar Udara Internasional Soekarno Hatta menuju Bandar Udara Internasional Adi Sucipto pada tanggal 7 Maret 2007. Penerbangan tersebut mengalami kecelakaan dengan keluar dari landasan (Runway Excursion) yang menyebabkan hancur dan terbakar serta mengakibatkan 23 orang meninggal dunia dan 35 orang luka berat (Fitra Iskandar, 2012). Atas kecelakaan tersebut, Flying Pilot dalam penerbangan tersebut yang bernama Capt. Marwoto Komar ditetapkan sebagai tersangka oleh kepolisian dan menjadi terdakwa dalam Pengadilan Negeri Sleman dengan dakwaan sebagai penyebab kecelakaan pesawat tersebut. Dalam persidangan tersebut Marwoto Komar dinyatakan bersalah melalui 
putusan nomor 348/Pid.B/2008/PN.SLMN dan divonis oleh hakim Pengadilan Negeri Sleman dengan pidana penjara selama 2 tahun karena dianggap bersalah melanggar pasal 479G huruf b KUHP serta pasal 479G hnuruf a KUHP, yakni karena kelalaiannya mengakibatkan pesawat udara celaka dan rusak serta tidak dapat digunakan lagi, serta menyebabkan 21 orang meninggal dan 35 orang luka berat.

Tindakan menghukum pilot oleh negara secara pidana di pengadilan umum maupun secara administratif merupakan tindakan hukum yang inkonsistensi dengan Annex 13 International Civil Aviation Organization (Selanjutnya disebut ICAO) tentang accident and serious incident investigation, alasannya adalah ketika terjadi kecelakaan maupun insiden serius, ICAO menghendaki untuk mencari apa yang salah sehingga menyebabkan kecelakaan atau insiden serius tersebut melalui kegiatan investigasi, sedangkan pemberian sanksi khususnya melalui peradilan umum merupakan kebalikan dari hal tersebut yang berfokus pada siapa yang salah (Paul Stephen, 2010: 226). Hadirnya judicial proceeding berdampak serius terhadap upaya perbaikan safety karena personel yang terlibat dalam kecelakaan maupun insiden serius karena mereka takut untuk berkontribusi pada upaya penyelidikan, maka hal ini akan menyebabkan ketidak cukupan safety information yang dibutuhkan (Agus Haryadi, Http://Www.Ilmuterbang. Com/Artikel-Mainmenu-29/KeselamatanPenerbangan-Mainmenu-48/761-CriminalInvestigation-Impacts-On-Flight-Safety). Ketika ketidak cukupan informasi tersebut terjadi, maka akan memberikan konsekuensi serius pada upaya memperbaiki apa yang salah (corrective action) sehingga menyebabkan kecelakaan maupun insiden serius dapat terulang kembali apabila tidak memperbaiki kesalahan sebelumnya dengan mengidentifikasi penyebab dari kesalahan yang menyebabkan accident maupun serious incident tersebut terjadi, mengingat salah satu alat yang paling efektif untuk meningkatkan keselamatan dan keamanan khususnya pada penerbangan sipil adalah belajar dari kesalahan yang telah terjadi sebelumnya untuk mencegah kejadian serupa terulang (ICAO, 2001: hlm 5-2). Oleh karena hal tersebut Annex 13 International Civil Aviation Organizationberusaha memisahkan antara segala upaya pidana maupun administratif dalam investigasi kecelakaan pesawat udara sipil. Pemisahan ini juga dapat membantu memastikan bahwa investigasi kecelakaan bebas dari konflik kepentingan yang dapat mempengaruhi objektifitas dan kredibilitas investigasi (Paul Stephen, 2010: 226) yang dapat menghambat upaya corrective action yang diharapkan melalui annex 13 International Civil Aviation Organization.

Implikasi dari hal-hal tersebut tentunya menghambat upaya corrective action sebagai langkah perbaikan agar kejadian serupa tidak terjadi kembali di masa yang akan datang, sehingga esensi tujuan positif yang di harapkan dari upaya memproses pilot dalam peradilan pidana dengan alasan sebagai upaya untuk mencegah agar orang tidak melakukan hal tersebut lagi serta demi melindungi kesejahteraan masyarakat (Zainal Abidin, 2005: 23) tersebut menjadi tidak tercapai, karena justru menimbulkan masalah terhadap upaya peningkatan keselamatan dan keamanan penerbangan sipil.

Annex 13 International Civil Aviation Organization mengenai accident and serious incident investigation mempunyai tujuan yaitu mencegah terjadinya kejadian serupa dan bukan bertujuan untuk menentukan kesalahan maupun pertanggung jawaban yang dapat dijadikan proses pemidanaan, atau sanksi administratif terhadap personel yang terlibat dalam kecelakaan maupun insiden serius tersebut (ICAO, 2001: 3-1),sehingga harapan mengenai corrective action dari 
accident dan serious incident yangmerupakan manifestasi dari tujuan Annex 13 International Civil Aviation Organization tersebut dapat tercapai, maka Indonesia sebagai contracting state terhadap Chicago Convention 1944, perlu menyerap dan menerapkan keseluruhan substansi dari Annex 13 ICAO yang salah satu poin mendasarnya adalah memisahkan proses hukum terhadap investigasi kecelakaan maupun insiden serius pesawat udara sipil (ICAO, 2001: 5-2).Annex sendiri merupakan standar dan rekomendasi praktis yang digunakan sebagai kerangka hukum bagi negara anggota ICAO untuk membuat hukum positif di negaranya sendiri, sehingga hal ini jelas tujuan dari Annex 13 ICAO adalah pencegahan terhadap kecelakaan maupun insiden serius dan bukan bertujuan untuk menghukum (Judith Nemsick Dan Sarah Gogal: 2012), namun pada Negara Indonesia, belum menyerap seluruhnya terhadap isi Annex, khususnya Annex 13 ICAO mengenai accident dan serious incident investigation.

Kecelakaan maupun insiden serius dalam sebuah pesawat terbang tidak pernah disebabkan oleh faktor determinatif tunggal, melainkan perpaduan di antara faktor-faktor: Teknis Pesawat, termasuk perawatan, Cuaca, Fasilitas Bandara dan pendukungnya, serta Human error(Bayu Sagita, 2009: 1). Apabila kebijakan menghukum (punitive action) di terapkan kepada pilot apabila terjadi kecelakaan maupun insiden serius, maka tindakan tersebut dapat dirasa menjadi hal yang tidak adil bagi Pilot. Ketidak adilan tersebut timbul dari pengaturan mutakhir yang menyimpang dengan derajat standar yang diterima secara publik dalam hal ini dunia penerbangan, namun ketidak adilan peraturan bukan alasan yang cukup untuk tidak mematuhinya, maka peraturan tersebut sudah merupakan sesuatu yang harus dilaksanakan (John Rawls, 1995: 454).

Berdasarkan uraian-uraian dari proses pemidanaan terhadap pilot hingga penghukuman terhadap pilot atas dasar peraturan yang dirasa kurang adil, maka dalam tulisan ini akan dilakukan pembahasan mengenai non punitive action terhadap Pilot pesawat udara sipil akibat kecelakaan dan insiden serius di Indonesia

\section{B. Metode Penelitian}

Jenis penelitian ini adalah penelitian hukum normatif atau doktrinal, dengan menggunakan pendekatan perundang-undangan dan perbandingan yang menggunakan teknik analisis bahan hukum deduktif sologisme dengan menggunakan premis minor dan premis mayor dan penarikan kesimpulan. Penelitian ini menggunakan teknik analisis bahan hukum studi kepustakaan atau library research.

\section{Hasil Penelitian danPembahasan}

1. Pilot pesawat udara sipil tidak dapat diberi sanksi akibat kecelakaan dan insiden serius

Punitive Action adalah tindakan untuk menghukum baik secara pidana maupun administratif terhadap seseorang yang dinyatakan bersalah menurut peraturan yang berlaku. Dalam konteks ini, punitive atau sanksi di berikan kepada Pilot pesawat udara komersil dalam menjalankan tugasnya sebagai penerbang apabila mengalami kecelakaan dan insiden serius. Secara umum, pemberian hukuman kepada pilot akibat accident dan serious incident merupakan hal yang layak untuk diterapkan kepada pilot tersebut karena telah membuat pesawat udara mengalami kecelakaan bahkan mengakibatkan korban jiwa apabila timbul korban jiwa, terlebih lagi apabila dalam memandang kejadian tersebut menggunakan pendekatan aliran klasik/ indeterminisme dan teori absolut. Dalam pendekatan ini, setiap kecelakaan dan 
insiden serius selalu yang dipersalahkan adalah pilot yang merupakan seseorang yang mengendalikan pesawat, namun hal tersebut di rasa tidak adil bagi pilot. Ketidak adilan tersebut beralasan bahwa di dalam sebuah kecelakaan dan insiden serius yang di anggap membahayakan penerbangan, tidak pernah ada faktor tunggal dalam peristiwa tersebut. Terdapat banyak faktor yang mempengaruhi terjadinya peristiwa tersebut yang membentuk rantai yang menyebabkan kecelakaan dan insiden serius, bahkan apabila salah satu mata rantai itu di putus, kecelakaan dan insiden serius tidak akan pernah terjadi(Agus Haryadi, Http://Www. Ilmuterbang.Com/Artikel-Mainmenu-29/ Keselamatan-Penerbangan-Mainmenu48/761-Criminal-Investigation-ImpactsOn-Flight-Safety). Hal ini dapat menjadi alasan bahwa ketika pilot dipersalahkan sebagai penyebab terjadinya suatu kecelakaan dan insiden serius, sehingga di proses dalam peradilan pidana seperti yang terjadi pada Capt. Marwoto Komar dalam kecelakaan penerbangan GA200, hal tersebut dirasa tidak adil bagi pilot, bahkan para pilot merasa tertekan dalam menjalankan profesinya karena ancaman hukuman apabila terjadi sesuatu yang membahayakan yang tentunya bukan hal yang di sengaja oleh pilot tersebut (Aviasi, 2015: 20).

Menurut pendekatan aliran determinisme. manusia dipandang tidak mempunyai kebebasan berkehendak, tetapi dipengaruhi oleh watak lingkungannya, sehingga dia tidak dapat dipersalahkan atau dipertanggungjawabkan dan dipidana. Aliran ini menolak pandangan pembalasan berdasarkan kesalahan yang subyektif sehingga menghendaki adanya individualisasi pidana yang bertujuan untuk mengadakan resosialisasi pelaku. Aliran determinisme menyatakan bahwa dalam sistem hukum pidana, tindak pidana sebagai perbuatan yang diancam pidana oleh undang-undang, penilaian hakim yang didasarkan pada konteks hukum yang murni atau sanksi pidana itu sendiri harus tetap dipertahankan.

A 1 iran Determinis m e mempertimbangkan dapat tidaknya seorang pelaku itu dijatuhi hukuman perlu diperhatikan beberapa pokok pikiran berikut ini,yakni bahwa (Purnadi Purbacaraka, 1982: 188-190):

a. Setiap orang itu pada dasarnya tidak mempunyai kehendak yang bebas dalam melakukan perbuatannya karena ia selalu tergantung pada berbagai faktor dan latar belakang yang pasti mempengaruhi; dan

b. Karena itu berbagai akibat yang ditimbulkan oleh perbuatannya itu pun dapat dikatakan bukan terjadi karena kehendaknya, melainkan berbagai akibat itu terjadi sebagai keterpaksaan yang tentunya berada di luar kesalahannya.

c. Karena itu maka orang yang melakukan sesuatu tindak pidana itu tidak dapat dituntut untuk bertanggung jawab atas perbuatannya atau dengan perkataan lain ia tidak dapat dijatuhi hukuman

Karena itu maka menurut aliran determinisme orang yang melakukan sesuatu tindakan tersebut tidak dapat dituntut untuk bertanggung jawab atas perbuatannya atau dengan perkataan lain ia tidak dapat dijatuhi hukuman. Ketiga pertimbangan dalam aliran determinisme tersebut, menjadi pendekatan terhadap non punitive action kepada pilot akibat kecelakaan dan insiden serius pesawat udara sipil. 
ad. a. Tidak adanya kehendak yang bebas oleh seseorang dalam melakukan perbuatannya karena ia selalu tergantung pada berbagai faktor dan latar belakang yang pasti mempengaruhi

Setiap kecelakaan dan insiden serius tidak pernah ada yang disebabkan oleh satu faktor, terdapat banyak faktor yang mempengaruhi seperti teknis Pesawat, termasuk perawatan, Cuaca, Fasilitas Bandara dan pendukungnya, serta Human error (Bayu Sagita, 2009: 1). Semuanya itu membentuk sebuah rantai yang tidak terputus namun saling mempengaruhi sehingga menyebabkan kecelakaan dan insiden serius terjadi. Apabila rantai tersebut terputus salah satunya, kecelakaan dan insiden serius pun tidak akan pernah terjadi. Contohnya yang baru terjadi adalah kecelakaan (accident) pesawat udara Indonesia Air Asia dengan nomor penerbangan QZ 8501 dan nomor registrasi pesawat PK-AXC dengan rute dari Bandar Udara Internasional Juanda menuju Bandar Udara Internasional Changi yang terjadi pada tanggal 28 Desember 2015. Kecelakaan terjadi di laut jawa dekat Selat Karimata yang menewaskan seluruh penumpang dan awak pesawat. Berdasarkan hasil investigasi KNKT, terdapat 5 penyebab kecelakaan pesawat udara tersebut yang saling berantai, yaitu : retaknya solder komponen RLTU (rudder limiter travel unit); kurang optimumnya sistem perawatan sehingga tidak terselesaikannya masalah pesawat hingga terjadi kerusakan yang berulang, flight dectcrew mereset sekring sehingga memutuskan aliran listrik ke FAC (flight augmentation Computer); rudder atau sayap tegak yang miring 2 derajat akibat rusaknya RLTU sehingga pesawat miring 2 derajat dan rolling 54 derajat; miskoordinasi antara kapten dengan first officer (kopilot) untuk memulihkan stall (KNKT, 2015).

Kejadian Indonesia Air Asia tersebut merupakan contoh dari kecelakaan pesawat udara sipil. Kejadian insiden serius dapat dicontohkan pada kejadian salah mendaratnya pesawat Sriwijaya Air dengan nomor penerbangan SJ563 dan registrasi pesawat PK-CKL dengan rute Bandar Udara Internasional Sepinggan, Balikpapan menuju Bandar Udara Internasional Juanda di Sidoarjo pada 27 Januari 2014. Pesawat udara tersebut mendarat di taxiway tepatnya di south taxiway (SP2 Taxiway) bukan di landasan pacu. Faktor yang berkontribusi terhadap kejadian tersebut adalah (KNKT, 2014); pertama karena lingkungan bandar udara yang menyebabkan ilusi bahwa SP2 taxiway terlihat seperti runway karena SP2 taxiwaylampunya terlihat lebih cerah dari pada landasan pacu aktif (active taxiway). Faktor kedua adalah Pilot mengubah lateral mode dari VOR LOC menjadi Heading Mode. Faktor yang ketiga adalah keputusan untuk melanjutkan pendaratan kemungkinan besar disumbangkan oleh tidak adanya informasi spasial yang terkait dengan keputusan go arroun terhadap kondisi sekitar yang tak menentu, serta informasi NOTAM (Notice to Airman) yang menjadi memory jangka pendek mengatasi kondisi tak menentu. Atas insiden serius salah mendarat tersebut, Pilot yang terlibat dikenakan sanksi grounded 
atau dilarang terbang (Https://News. Detik.Com/Berita/2490932/InsidenLanding-Di-Bandara-Juanda-PilotSriwijaya-Dan-Lion-Kena-Sanksi).

Kecelakaan dan insiden serius tersebut merupakan bukti bahwa setiap kecelakaan dan insiden serius tidak pernah disebabkan oleh karena faktor tunggal, selalu ada rantai yang saling terhubung untuk menghasilkan sebuah kecelakaan dan insiden serius, oleh karena itu berdasarkan teori determinasi, pilot tidak mempunyai kehendak untuk terjadinya kecelakaan dan insiden serius karena ia selalu tergantung pada faktor dan latar belakang yang pasti saling mempengaruhi. Oleh karena itu apabila pilot di pidanakan atau di beri sanksi akibat sebuah kecelakaan dan insiden serius, hal tersebut dirasa kurang fair, sebab tentunya pilot tidak ada kehendak untuk mencelakakan dirinya sendiri maupun orang lain dalam melaksanakan tugasnya.

Apabila seorang pilot tetap di proses dalam pidana, maka yang menjadi barang bukti tentunya adalah black box, padahal berdasarkan annex 13 ICAO, black box dilarang digunakan untuk barang bukti dalam persidangan hukum. Hal ini dikarenakan apabila data black box di gunakan sebagai barang bukti, maka penyelidikan dalam rangka investigasi penyebab kecelakaan pesawat menjadi terganggu, padahal black box sangat penting untuk mengetahui penyebab dari suatu kecelakaan supaya apa yang salah dapat diperbaiki sehingga tidak terjadi lagi dikemudian hari.

Kecelakaan maupun insiden serius tidak terjadi oleh karena kegagalan individu, melainkan hasil dari tumpuan atau keselarasan yang saling berkaitan sehingga menjadi faktor-faktor yang berkontribusi yang mengakibatkan kecelakaan maupun insiden serius tersebut, sehingga sumber dari suatu kecelakaan maupun insiden serius adalah sistem bukan bagian dari komponennya, akibatnya menjadi sebuah ketidak adilan bagi seorang pilot ketika menjadi objek yang disalahkan, apabila hal ini terjadi akan menyebabkan sifat defensif, proteksionis, polarisasi sehingga berimplikasi pada hilangnya informasi penting yang berkaitan tentang kecelakaan maupun insiden serius tersebut (Palmer, L. I., Emanuel, L. L, 2001).

ad. b.c. Berbagai akibat yang ditimbulkan oleh perbuatannya itu pun dapat dikatakan bukan terjadi karena kehendaknya, melainkan berbagai akibat itu terjadi sebagai keterpaksaan yang tentunya berada di luar kesalahannya

Berdasarkan pertimbangan kedua untuk menentukan dihukum atau tidaknya seseorang karena perbuatan dari pendekatan aliran determinasi adalah akibat yang ditumbulkan oleh perbuatannya itu pun dapat dikatakan bukan terjadi karena kehendaknya, melainkan berbagai akibat itu terjadi sebagai keterpaksaan yang tentunya berada di luar kesalahannya. Pertimbangan ini dapat diterapkan ketika pilot dalam mengendalikan pesawat udara mengalami hard landing, over/ under shoot, go around, divert dan sebagainya. Berbagai hal tersebut di anggap sebagai sesuatu yang membahayakan atau indikasi bahaya 
bagi penerbangan, namun perlu di ketahui bahwa akibat perbuatan seorang pilot misalnya adalah hard landing, over/under shoot, go around, divert da`n sebagainya adalah akibat yang di timbulkan bukan terjadi karena kehendaknya melainkan keterpaksaan yang tentunya di luar kesalahannya.

Menyikapi Peraturan Menteri Perhubungan Nomor 30 Tahun 2015 tentang Pengenaan Sanksi Administratif Terhadap Pelanggaran di Bidang Penerbangan, terdapat ketentuan yang dapat di terjemahkan bahwa pilot dalam melaksanakan tugasnya apabila mengalami sesuatu yang dapat membahayakan penerbangan, maka akan di beri sanksi. Seperti yang telah di paparkan sebelumnya bahwa hard landing, over/under shoot, go around, dan divert merupakan sesuatu yang dianggap membahayakan dan atau mengindikasikan sebuah bahaya dalam penerbangan, padahal hal hal tersebut adalah normal meskipun dalam batasan tertentu dapat terjadi accident maupun serious incident.

Apabila oleh karena akibat yang ditimbulkan tersebut, seorang pilot mendapatkan hukuman, maka secara langsung maupun tidak langsung akan berdampak negatif pada keselamat penerbangan sipil. Contohnya adalah ketika seorang pilot pada titik minimum decisionaltitude (selanjutnya disebut MDA), sudah memberi declare untuk landing, namun ternyata setelah melewati titik MDA terdapat windshear (perubahan arah angin mendadak yang ekstrim), hal tersebut membuat pesawat menjadi unstable sehingga berbahaya apabila pilot memutuskan untuk terus mengupayakan landing, satu satunya cara adalah dengan melakukan go arround, akan tetapi dengan adanya Peraturan Menteri Nomor 30 Tahun 2015 tentang Pengenaan Sanksi Administratif Terhadap Pelanggaran di Bidang Penerbangan tersebut, maka membuat pilot takut apabila melakukan go arround karena takut akan sanksi yang akan di berikan, karena go arround dianggap sebagai bentuk yang dapat membahayakan penerbangan.

Contoh selanjutnya adalah hard landing bagi pesawat yang mendarat. Sebenarnya hard landing dalam batasan tertentu masih diperbolehkan, akan tetapi dengan adanya Peraturan Menteri Nomor 30 Tahun 2015 tentang Pengenaan Sanksi Administratif Terhadap Pelanggaran di Bidang Penerbangan, hard landing dianggap sebagai sesuatu yang membahayakan, padahal hard landing bisa di sebabkan oleh banyak faktor bahkan dilakukan demi alasan keselamatan. Contohnya apabila cuaca buruk, pilot akan landing namun tetap mengusahakan soft landing, maka hal tersebut akan sangat berbahaya, karena dapat menyebabkan pesawat tergelincir hingga overshoot dan runway excursion, sehingga ketika pesawat mendarat yang diutamakan bukan hard landing maupun soft landing, melainkan positive landing.

Berdasarkan dua komponen yang dijadikan instrumen untuk menentukan apakah seseorang dapat dihukum atau tidak, maka menurut aliran determinisme pilot sebaiknya tidak dapat dituntut untuk bertanggung jawab atas perbuatannya atau dengan perkataan lain ia tidak dapat dijatuhi hukuman apabila 
terjadi accident maupun serious incident, karena apabila terjadi hal-hal tersebut, tentunya diluar kehendak pilot, namun tentunya untuk menentukan hal tersebut perlu adanya Majelis Profesi Penerbang sebagai majelis profesi yang menentukan apakah tindakan pilot termasuk sebagai unintentional unsafe act atau intentional unsafe act seperti yang telah dipaparkan di atas. Apabila tindakan pilot termasuk kategori intentional violation, maka majelis profesi penerbang menyerahkan kasus tersebut kepada ranah hukum.

Violation adalah pelanggaran, perbedaan yang mendasar antara honest mistake dengan violation adalah pada sifat kesengajaannya (Agus Hariadi, Http://.Ilmuterbang. Com/Artikel-Mainmenu-29/ Keselamatan-PenerbanganMainmenu-48/798-Human-FactorAnalysis). Contoh dari violation adalah pada kasus Dirgantara Air Service dengan Nomor Penerbangan AW 3130 pada 18 November 2000 di Datah Dawai, Kalimantan Timur. Dalam penerbangan tersebut, pesawat udara mengalami kecelakaan, yang berdasarkan hasil investigasi oleh KNKT, ternyata Pilot sengaja memperbolehkan beban yang diterima pesawat melebihi dari standar perusahaan. Faktor kedua adalah Pilot sengaja memperbolehkan pesawat diisi penumpang melebihi batas kemampuan pesawat yaitu dengan melakukan kesepakatan pembayaran dari penumpang kepada pilot untuk dapat di muat dalam penerbangan tersebut. Pada kecelakaan ini, pilot jelas sengaja menyalahi prosedur atas dasar motivasi pribadi, sehingga dalam kasus ini, Pilot boleh untuk dipidanakan. Sehingga hal tersebutlah yang mendasari perbedaan antara violation dengan honest mistake dengan pendekatan aliran Determinisme untuk menentukan apakah Pilot dapat dihukum akibat accident atau serious incident dalam upaya mewujudkan just culture dalam penerbangan di dunia. Melalui aliran determinisme dapat diketahui bahwa tingkah laku seseorang merupakan hasil interaksi antara kepribadian dan lingkungan hidup seseorang, bukan pelaku tindak pidana yang hendaki perbuatan pidana, tetapi situasilah yag mendorongnya demikian. Situasi dalam hal ini mencangkup personal dan moral, sedangkan lingkungan hidup tersebut di atas menjadikannya sebagai mata rantai sebab akibat, eksternal dan internal yang menentukan dia melakukan hal yang di anggap dimata hukum sebagai sebuah penyimpangan (Dekker, 2002: $3)$.

\section{Inkonsistensi Terhadap Konvensi Chicago Annex 13 International Civil Aviation Organization}

Penyelenggaraan penerbangan sipil baik domestik, regional, maupun internasional harus mengacu pada ketentuan dan norma hukum internasional maupun hukum nasional yang berlaku demi menciptakan keselamatan dan keamanan penerbangan sipil. Penyelenggaraan penerbangan sipil tersebut di atur dalam berbagai konvensi internasional. Dalam hukum udara internasional, terdapat Konvensi Chicago 1944 sebagai konstitusi penerbangan sipil yang menjadi acuan bagi negara contracting state untuk membuat hukum nasionalnya mengenai penerbangan sipil. Sebagai contracting state, termasuk Negara Indonesia, harus mengharmonisasikan 
antara ketentuan hukum internasional, dalam hal ini Konvensi Chicago 1944 dengan hukum nasionalnya sebagai harmonisasi hokum (Michael Tilde, 2008: 60-68)demi melindungi kepentingan keselamatan dan keamanan penerbangan sipil internasional (Jiefang Huang, 2008: 72).

Pembahasan mengenai kecelakaan dalam Konvensi Chicago 1944, tertuang dalam rumusan Annex 13 International Civil Aviation Organization mengenai accident and serious incident investigation yang mengesampingkan judicial proceeding beralasan bahwa dalam penyelidikan kecelakaan maupun insiden serius menghendaki untuk mencari apa yang salah sehingga menyebabkan kecelakaan atau insiden serius tersebut melalui kegiatan investigasi, sedangkan pemberian sanksi khususnya melalui peradilan umum merupakan kebalikan dari hal tersebut yang berfokus pada siapa yang salah(Paul Stephen, 2010: 226). Oleh karena hal tersebut Annex 13 International Civil Aviation Organization memisahkan segala upaya pidana maupun administratif dalam investigasi kecelakaan pesawat udara sipil (ICAO, 2001: 5-2) yang dapat disebut pula dengan non punitive action. Pemisahan ini bertujuan memastikan bahwa investigasi kecelakaan yang objektif sesuai ketentuan Annex 13 International Civil Aviation Organization yang tertuang dalam kalimat: "The sole objective of the investigation of an accident or incident shall be the prevention of accidents and incidents. It is not the purpose of this activity to apportion blame or liability". Dengan dipisahkannya mencari siapa yang salah melalui punitive action terhadap investigasi kecelakaan dan insiden serius akan menghasilkan investigasi yang dan bebas dari konflik kepentingan yang dapat mempengaruhi objektifitas dan kredibilitas investigasi(Paul Stephen, 2010: 226) dan mencari siapa yang salah sehingga dapat menghambat upaya corrective action yang diharapkan melalui annex 13 International

\section{Civil Aviation Organization.}

Oleh karena itu, Indonesia sebagai salah satu contracting state Konvensi Chicago 1944 dan yang merupakan anggota International Civil Aviation Organization, perlu menerapkan non punitive action dalam rumusan hukum nasional mengenai penerbangan khususnya ketika terjadi kecelakaan maupun insiden serius. Akan tetapi Indonesia belum mempunyai rumusan hukum nasional yang tegas mengenai non punitive action, bahkan sebagian instrumen hukum mengenai kecelakaan dan insiden serius masih bersifat punitive.

Penerapan prinsip just culture tersebut dapat diimplementasikan ke dalam hukum nasional. Sebagai contracting state ICAO, Indonesia wajib mengimplementasi hal tersebut, akan tetapi dalam aturan hukum nasional, masih dapat dijumpai berbagai hal yang tidak sesuai dengan prinsip just culture berupa punitive action. Beberapa aspek tersebut khususnya tertuang dalam berbagai peraturan menteri diatas, seperti pemberian sanksi terhadap hard landing, melakukan pendaratan tanpa roda, approach to land kurang dari persyaratan cuaca minimum, dan sebagainya merupakan hal hal yang berdasar klasifikasi error, banyak tindakan yang dapat dikenai sanksi tersebut tidak masuk ke dalam kategori violation. Dalam prinsip just culture menyadari bahwa setiap manusia bisa melakukan kesalahan, bahkan selama teknologi masih di operasikan oleh manusia, kesalahan yang biasa disebut sebagai human error pasti masih terjadi sehingga kesalahan tak sengaja sebagai yang dilakukan oleh manusia merupakan hal yang sangat wajar. Oleh karena itu output dari just culture adalah pembelajaran agar dapat menciptakan sebuah sistem sebagai solusi agar kelemahan dari manusia tersebut dapat diminimalisir, sehingga ketika terjadi kecelakaan maupun insiden serius perlu adanya perbaikan sebagai correctiveaction supaya kejadian serupa 
tidak terulang kembali, oleh karena itu dalam Annex 13 International Civil Aviation Organization mengenai accident and serious incident investigation mengesampingkan dan memisahkan judicial proceeding, seperti yang tertuang dalam rekomendasi Annex tersebut: "Any judicial or administrative proceedings to apportion blame or liability should be separate from any investigation conducted under the provisions of this Annex". Pemisahan tersebut dilakukan karena hadirnya judicial proceeding berdampak serius terhadap upaya perbaikan safety karena personel yang terlibat dalam kecelakaan maupun insiden serius, sebab mereka takut untuk berkontribusi pada upaya penyelidikan, maka hal ini akan menyebabkan ketidak cukupan safety information yang dibutuhkan(Agus Haryadi, Http://Www. Ilmuterbang.Com/Artikel-Mainmenu-29/ Keselamatan-Penerbangan-Mainmenu48/761-Criminal-Investigation-Impacts-OnFlight-Safety). Hal tersebut memberikan konsekuensi yang sangat serius pada upaya safety improvement sebagai corrective action sehingga menyebabkan kecelakaan maupun insiden serius kemungkinan besar dapat terulang kembali.

Konvensi Chicago menghasilkan produk hukum yang antar negara memiliki keseragaman dalam keselamatan dan keamanan penerbangan sipil yang di sebut sebagai standard dalam ICAO, sehingga semua contracting state harus memenuhi standard tersebut (Van Antwepen, 2002: 35) sebagai tanggung jawab negara terkait keselamatan dan keamanan penerbangan sipil. Tanggung jawab dalam menciptakan keselamatan dan keamanan penerbangan tersebut merupakan kewajiban yang harus di lakukan demi mencapai tujuan dari ICAO, sehingga kewajiban tersebut dapat sebagai kewajiban erga omnes(Febilita, 2010:320). Sebagai masyarakat internasional, Indonesia harus mentaati ketentuan hukum internasional khususnya yang telah diratifikasi, sehingga dalam konteks ICAO, Indonesia harus mengakomodirnya dalam setiap instrumen hukum nasional.

Standar mengenai investigasi kecelakaan dan insiden serius dimuat dalam Annex 13 International Civil Aviation Organization yang merupakan ketentuan internasional, dimana Indonesia sudah meratifikasinya. Implementasi terhadap ketentuan tersebut tertuang mulai dari undang-undang yaitu Undang-Undang Nomor 1 Tahun 2009 Tentang Penerbangan hingga dengan peraturan menteri. Rumusan definisi mengenai kecelakaan dalam Undang-Undang Nomor 1 Tahun 2009 Tentang Penerbangan adalah peristiwa pengoperasian pesawat udara yang mengakibatkan kerusakan berat pada peralatan atau fasilitas yang digunakan dan atau korban jiwa atau luka serius. Sementara rumusan definisi mengenai insiden serius adalah pengoperasian pesawat udara yang hampir menyebabkan kecelakaan.

Sesuai yang telah diuraikan sebelumnya, implementasi hukum nasional harus menyesuaikan kaidah hukum internasional, terlebih lagi hal tersebut sudah menjadi erga omnes, termasuk salah satunya mengenai kewajiban menciptakan keselamatan dan keamanan penerbangan sipil. Akan tetapi, didalam upaya pelaksanaan menciptakan keselamatan dan keamanan penerbangan sipil tersebut, kecelakaan dan insiden serius masih terjadi oleh berbagai faktor. Ketika terjadi kecelakaan maupun insiden serius perlu adanya perbaikan sebagai correctiveaction supaya kejadian serupa tidak terulang kembali, oleh karena itu dalam Annex 13 International Civil Aviation Organization mengenai accident and serious incident investigation mengesampingkan dan memisahkan judicial proceeding, seperti yang tertuang dalam rekomendasi Annex tersebut: "Any judicial or administrative proceedings to apportion blame or liability should be separate from any investigation conducted under the provisions of this Annex". Pemisahan tersebut 
dilakukan karena hadirnya judicial proceeding berdampak serius terhadap upaya perbaikan safety karena personel yang terlibat dalam kecelakaan maupun insiden serius, sebab mereka takut untuk berkontribusi pada upaya penyelidikan, maka hal ini akan menyebabkan ketidak cukupan safety information yang dibutuhkan. (Agus Haryadi, Http://Www. Ilmuterbang.Com/Artikel-Mainmenu-29/ Keselamatan-Penerbangan-Mainmenu48/761-Criminal-Investigation-Impacts-OnFlight-Safety). Hal tersebut memberikan konsekuensi yang sangat serius pada upaya safety improvement sebagai corrective action sehingga menyebabkan kecelakaan maupun insiden serius kemungkinan besar dapat terulang kembali.

Pemberian sanksi terhadap kesalahan manusia dapat dikatakan sebagai kriminalisasi terhadap error, sehingga just culture yang menjadi pondasi safety management system menjadi diabaikan. Pengabaian tersebut tentunya dilakukan dengan terus berjalannya blame culture yang tentunya menghambat corrective action akibat reporting system oleh personel yang membawa informasi penting tidak tersampaikan. Dalam arti lain, melakukan pemberian sanksi terhadap kesalahan yang tidak disengaja, sama sekali tidak menyelesaikan masalah, karena permasalahan terdapat pada sistemnya bukan pada personelnya apabila setiap error dipandang berdasarkan prinsip just culture. Sekalipun personel tersebut dihukum akibat unsafe act yang unintentionally, efek jera sebagai tujuan dari teori pembalasan pemidanaan, tidak dapat tercapai, bahkan justru berkonsekuensi serius terhadap safety improvement akibat chain of factors dari kecelakaan maupun insiden serius yang tidak diketahui akibat minimnya atau bahkan tidak adanya informasi tersebut sehingga corrective action tidak terwujud, namun apabila unsafe act yang dilakukan oleh personel tersebut bersifat intentionally, maka berdasar sifat dari prinsip just culture yang tidak memberikan toleransi terhadap kesalahan yang disengaja, maka kesalahan manusia yang disengaja tetap harus dihukum sebagai intentional violation. Oleh karena itu untuk mendeterminasi suatu tindakan yang disengaja atau tidak, perlu adanya investigasi dari pihak yang berwenang, dalam hal ini adalah komisi nasional kecelakaan transportasi (KNKT), namun laporan akhir dari KNKT tersebut tidak dapat dijadikan dasar blaming terhadap personel penerbang yang terlibat, kecuali berdasarkan laporan KNKT terdapat indikasi yang menjurus kepada unsafe act yang disengaja berupa terorisme, bunuh diri, pemakaian narkoba, dan kriminalitas lainnya.

\section{Simpulan}

Urgensi penerapan non punitive action terhadap pilot akibat kecelakaan dan insiden serius pesawat udara sipil adalah karena pemberian sanksi terhadap pilot akibat kecelakaan maupun insiden serius, akan menghalangi upaya corrective action karena ketidakcukupan informasi yang diakibatkan kecenderungan personel yang terlibat dalam menutupi informasi mata rantai penting yang berkontribusi terhadap kecelakaan maupun insiden serius apabila terdapat ketakutan akan pemberian sanksi akibat safety report yang diberikan, selain itu pemberian sanksi terhadap personel yang terlibat tersebut adalah sebuah tindakan yang inkonsisten dengan annex 13 ICAO oleh Indonesia yang merupakan contracting state Konvensi Chicago 1944, oleh karena itu berdasarkan aliran determinisme dan prinsip just culture, dalam hal ini pilot tidak dapat diberi sanksi akibat kecelakaan maupun insiden serius, namun sesuai prinsip just culture tetap tidak memberi toleransi terhadap intentional violation.

\section{E. Saran}


1. Bagi Pemerintah, perlu dilakukannya evaluasi dan memperbaharui setiap peraturan yang pada dasarnya sebenarnya bertujuan untuk keselamatan penerbangan, namun berbalik justru membahayakan keselamatan penerbangan itu sendiri atau membentuk hazard baru dengan melanggar prinsip just culture. Serta perlu di bentuknya Majelis Profesi Penerbang sesuai dengan amanat UndangUndang Nomor 1 Tahun 2009 Tentang Penerbangan. Lalu perlunya penerapan sistem hukuman (punitive action) yang produktif dan efektif, dalam arti tidak membuat aturan yang mengandung sanksi yang justru kontra produktif dengan keselamatan penerbangan, namun hal ini juga perlu didukung dengan safety culture.

2. Bagi penegak hukum, dalam hal untintentional unsafe act sebaiknya pilot tidak di diproses secara hukum karena berdasarkan pendekatan aliran Determinisme dan just culture hal tersebut bukan sesuatu yang harus membuat pilot untuk dihukum.

3. Bagi penumpang, sebaiknya mematuhi setiap peraturan keselamatan penerbangan, karena terkadang perilaku penumpang itu sendiri yang membahayakan penerbangan, seperti tidak mematikan peralatan komunikasi.

4. Bagi masyarakat, sebaiknya jangan langsung menuduh pilot sebagai penyebab utama sebuah kecelakaan maupun insiden serius, karena tentunya pilot dalam melaksanakan tugasnya benar benar mengutamakan keselamatan dan keamanan penerbangan sipil dan apabila terjadi kecelakaan itu merupakan hal yang diluar kendalinya serta banyak faktor yang mempengaruhinya dalam kata lain tidak ada faktor tunggal yang menyebabkan kecelakaan dan insiden serius tersebut terjadi.

\section{F. Daftar Pustaka}

\section{Buku}

Dekker, S. W. A. 2002. The field guide to human error investigations. Bedford, UK: Cranfield University Press of Aldershot.

John Rawls. 1995. A Theory of Justice : Teori Keadilan. Yogyakarta: Pustaka Pelajar.

Jiefang Huang. 2008. Aviation Safety. ICAO and Obligation Erga Omnes. Oxford: Oxford University Press. 2008.

Judith Nemsick dan Sarah Gogal. 2012. Criminalization Aviation: Placing Blame Before Safety. American Bar Association

Lawrence M. Friedman. 2011. Sistem Hukum Perspektif Ilmu Sosial. Bandung: Nusamedia.

Palmer, L. I., Emanuel, L. L., \& Woods, D. D. 2001. Managing systems of accountability for patient safety. Washington, DC: National Health Care Safety Council of the National Patient Safety Foundation.

Purnadi Purbacaraka \& Ridwan Halim. 1982. Filsafat Hukum Pidana Dalam Tanya Jawab. Jakarta: Rajawali.

William J. Chamblis dan Robert B. Seidman. 1971. Law, Order, and Power.

Zainal Abidin. 2005. Penghakiman Massa. Jakarta: Erlangga.

\section{Jurnal}

Michael Milde. 2008. "The International Civil Aviation Organization: After 50 Years And Beyond."Australian International Law Journal: Eleven International Publishing 
Paul Stephen. 2010. Journal of Airlaw and Commerce.Independence of Aviation Safety Investigation Authorities: Keeping the Foxes From The Henhouse. Issue 2. volume 75 .

\section{Penulisan Ilmiah}

Agus Haryadi. 2014. http://www.ilmuterbang. com/artikel-mainmenu-29/keselamatanpenerbangan-mainmenu-48/761 criminal-investigation-impacts-onflight-safety. diakses pada 11 November 2016, 23.00. WIB

. 2015. http://www.ilmuterbang.com/ artikel-mainmenu-29/keselamatanpenerbangan-mainmenu-48/798human-factor-analysis. diakses pada 11 November 2016, 22.00 WIB

Bayu Sagita Wijaya. 2015.Pertanggungjawaban Pidana Pilot (Kapten Terbang) Atas Terjadinya Kecelakaan Pesawat Udara Dari Perspektif Undang-Undang Nomor 1 Tahun 2009 Tentang Penerbangan. Skripsi. Universitas Sumatera Utara.

Febilita. Ketentuan Annex XIV Konvensi Chicago 1944 Mengenai Standar Internasional Bandar Udara Bagi Keselamatan Penerbangan dan Implementasinya dalam Hukum Udara Nasional.

James Reason. 2004. A Road Map To A Just Culture. Gain.

Roderic D. Van Dam. ASPA Regional Seminar 10-11 April 2007. Mexico

\section{Surat Kabar Elektronik}

Aviasi. 2015. Menyikapi PM 30 Tahun 2015.

Fitra Iskandar. 2013. http://news. $\mathrm{metrot}$ v n e w s . co m/ r e a d / 2015/03/07/367729/2007-pesawat- garuda-ga-200-terbakar-23-orangtewas. Diakses Pada 19 Desember 2016, Pukul 23.00 WIB

https://News.Detik.Com/Berita/2490932/ Insiden-Landing-Di-Bandara-JuandaPilot-Sriwijaya-Dan-Lion-Kena-Sanksi. Diakses Pada 19 Januari 2017, Pukul 23.50 WIB

\section{Peraturan Perundang-undangan}

ICAO. 2001. Annex 13 International Civil Aviation Organization. Session 9. No.5.4.1.Resolusi Majelis Umum ICAO Doc 9848.

Van Antwepen. Resolusi Majelis Umum ICAO Doc 9848

\section{Laporan Investigasi}

KNKT. 2014 Aircraft Accident Investigation Report PT Sriwijaya Air Boeing 737300; PK-CKL.

KNKT. 2014. Aircraft Accident Investigation Report PT Air Asia Indonesa Airbus A320-216; PK-AXC. 